\title{
Die debatteerbare kerkregtelike relevansie tussen 1618, 1816 en 1951 in verhouding tot die Kerkorde van die Nederduitsch Hervormde Kerk van Afrika
}

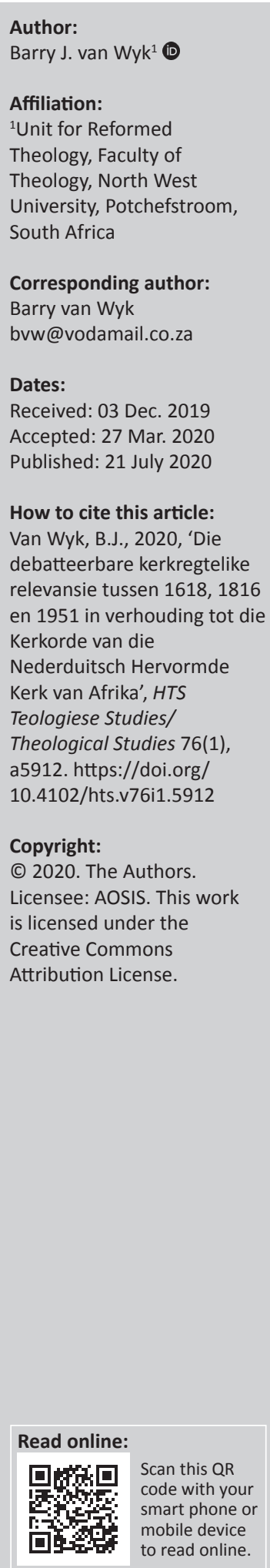

The debatable church orderly relevance between 1618, 1816 and 1951 in relation to the church order of the Netherdutch Reformed Church of Africa: The above-mentioned dates from the past, although distant from each other, are linked to each other and influential in the church law debate, even in recent times. The intention of this paper is to link the dates as well as the events associated with the mentioned dates from the past with the church order of the Netherdutch Reformed Church of Africa which was determined during the church's 71st synod meeting during 2016. Churches in South Africa originated from the 16th century Reformation should accommodate each other even with some different viewpoints especially in connection with church law as formulated and practised in different churches.

Contribution: The contribution of this paper is to point out that the relation between the mentioned dates indicate important milestones in the church orderly past, in the Netherlands and in South Africa and should be treated with caution, especially in reference to the church order of the Netherdutch Reformed Church of Africa.

Keywords: Dordt 1618; church order; church order NHKA; Algemeen Reglement; relevance.

\section{Ter inleiding}

Bogenoemde jaartalle uit die verlede verwoord ' $n$ besondere kerkregtelike relevansie wat oënskynlik tot die verlede behoort, maar klaarblyklik die vermoë het om te duur, selfs tot op hede. Elkeen van genoemde datums verwoord besondere momente uit die kerkregtelike verlede wat inderdaad invloed uitgeoefen het op die kerkregtelike verloop sedertdien. In hierdie artikel word gepoog om die genoemde historiese momente met mekaar in verband te bring ter wille van insig in die kerkordelike denke soos verwoord in die Kerkreg eie aan die Nederduitsch Hervormde Kerk van Afrika, met besondere verwysing na die kerkorde wat tydens die 71ste Algemene Kerkvergadering in 2016 vasgestel is. Die artikel spruit uit die oortuiging dat kerke in Suid-Afrika wat uit die Reformatoriese Kerkreg put, bepaalde nuanse verskille vertoon wat met respek hanteer moet word, met die verwagting dat debat oor die ander kerk sal strook met die werklikheid (vgl. Nel 2019).

Hermeneuties sou bygevoeg kon word dat daar wesenlik net één kerk is, en dit kom daarop neer dat elke kerk poog om 'n verskyningsvorm van die een, heilige en algemene Christelike kerk te wees waaroor dit in die Apostolicum gaan. Kerklike meerderwaardigheid of kerkisme, om welke rede ook al, ontsier die kerklike lewe en bedreig die gemeenskap van geloof. Boonop is sodanige kerklike uitwasse in stryd met die Skrif wat 'n inklusiewe kerkwees verwoord (Matt 28:19-20) in kontras met 'n eie kerklike eksklusivisme wat moontlik aan meerderwaardigheid te wyte is.

\section{Die relevansie van 1618 in die hedendaagse kerkregtelike debat}

Die datum verwys na die Sinode van Dordt wat in sitting was van 13 November 1618 tot en met 29 Mei 1619 (Doornbos 1967:38; Pont 1981:168) in die stad Dordrecht in die huidige Nederland. Die gebou waarbinne die Sinode plaasgevind het, bekend as die Kloveniersdoelen (Florijn 1987:61), is ongelukkig sedertdien afgebreek.

Die verrigtinge van die Sinode by Dordrecht staan veral in verband met die meningsverskil tussen die Remonstrante en Contra-Remonstrante wat tydens die Sinode, in die teenwoordigheid van 'n aantal buitelandse afgevaardigdes asook verteenwoordigers van die regering, op die spits gedryf is. Naas die Leerreëls is die kerkorde ook opnuut vasgestel wat wesenlik die kerkorde is wat sedert die 
Sinode van Emden 1571 geformuleer is en wat, na verloop van verskillende sinodes daarna, 'n bepaalde kerkordelike afsluiting vind in die Sinode van Dordrecht 1618-1619 (Haitjema 1951:23). Merkwaardig genoeg was Dordt die einde van 'n reeks sinodale sittings aangesien die volgende sinodale vergadering in totaal ander omstandighede plaasvind.

Sedert Dordt 1618-1619 tot en met 1816 verloop 198 jaar waarin daar geen sinodale byeenkoms soos tussen 1571 en 1618 , plaasvind nie. Haitjema meen dit is een van die redes waarom Dordt so ' $n$ besondere waardering ontvang het.

Daarnaas is dit ook so dat Dordt met verloop van tyd gewysig is (Spoelstra 1989:22) deur die verwydering van artikels wat in verband staan met die invloed van die owerheid op die kerk (Dordt artikel IV, XXXVII, vgl. Kersten 1980:177-178, 184), bekend as die patronaatsreg, wat as gevolg van die verandering van die verhouding tussen kerk en owerheid geen doel meer dien nie (Haitjema 1951:24).

Naas veranderde politieke omstandighede wat invloed op die kerklike lewe uitgeoefen het, volg ook kerklike spanning as gevolg van die instelling van die Algemeen Reglement van 1816, wat kerklike afskeidings tot gevolg het in 1834 en 1886, laasgenoemde bekend as die Doleansie (Haitjema 1964:242). Dit bring ook kerkordelik mee dat met verloop van tyd 'n keuse gemaak word - enersyds vir die handhawing van die kerkorde van Dordt, maar andersyds vir 'n nuwe kerkorde wat deur die Nederlandse Hervormde Kerk geformuleer is wat op 01 Mei 1951 in werking gestel is. Die spanning wat veral sedert 1886 in Nederland tussen Gereformeerd en Hervormd bestaan, word ook kerkordelik merkbaar as ' $n$ keuse vir Dordt óf vir die Algemeen Reglement van 1816 [sic], of minstens deur laasgenoemde beïnvloed is, omdat met verloop van tyd die mening vorm dat kerkordes wat nie op die kerkorde van Dordt gebaseer is nie, sonder meer onder invloed staan van die Algemeen Reglement. Die Nederlandse Hervormde Kerk formuleer 'n nuwe kerkorde wat uiteindelik op 01 Mei 1951 in gebruik geneem word en duidelik van die Algemeen Reglement van 1816 verskil.

Ten spyte van die besondere betekenis wat aan die kerkorde tydens die Sinode van Dordt van 1618-1619 verleen is en veral in die lig van die betekenis wat met verloop van tyd aan die kerkorde toegeken is, was daar nie sprake van'n algemene aanvaarding nie - ook nie deur die owerheid nie. In die provinsies Holland, Friesland en Zeeland is die kerkorde nie aanvaar nie, maar wel in die provinsies Utrecht, Gelderland en Overijsel (vgl. red. Selderhuis 2006:436). Dit is opvallend dat in die provinsie Holland waaronder die klassis Amsterdam ingesluit was en wat sedert 1652 tot 1814 verantwoordelikheid vir die Kaap aanvaar het, die Dordtse kerkorde nooit gegeld het nie (Haitjema 1951:31; Pont 1981:170; Spoelstra 1989:21).

Dit is sekerlik vanselfsprekend om te aanvaar dat die kerkorde van Dordt van 1618-1619 eie aan die tyd is waarin die kerkorde tot stand gekom het en radikaal verskil van die hedendaagse situasie waarin die kerk leef.
Nader beskou handel die Dordtse kerkorde oor dienste (ampte) (art. 2-28), kerklike samekomste (vergaderings) (art. 29-52), die leer, sakramente en seremonies (art. 53-70), asook oor sensuur en kerklike vermanings (art. 71-83), gevolg deur drie slotartikels (art. 84-86). Die kerkorde bestaan altesaam uit 86 artikels.

Haitjema (1951:27-31) waardeer die Dordtse kerkorde van 1618-1619 positief as 'n konsolidasie van 'typischGereformeerde kerkrecht' soos dit kenmerkend is van 'n tipies presbiteriaal-sinodale sisteem van kerkregering.

Die ampte voorafgaan vorm die hoofpyler van die kerkorde met besondere verwysing na die amp van die ouderling wat deur Haitjema getipeer word as die 'oervorm van alle gewone geestelijke ambten'. 'n Predikant is as sodanig dan 'n lerende ouderling en 'n diaken, 'n priesterlik-dienende ouderling. Daarmee is deur die vooropstelling van presbiteriaal in die dubbelbegrip van presbiteriaal-sinodaal enige vorm van kongregasionalisme of episkopalisme afgewys. Eersgenoemde (presbiteriaal) gee aan die tweede 'n Calvinistiese kleur wat daarop neerkom dat dit ' $n$ vergadering is waar die ampte byeenkom, 'n amptelike vergadering wat uiteindelik niks anders is nie as 'n groot kerkraadsvergadering. Sodoende word afgegrens teen independentisme of kongregasionalisme wat die neiging het om sinodale vergaderings te sien as ' $n$ vergadering van afgevaardigdes van plaaslik outonome gemeentes wat as kerke ter vergadering kom, met 'n bepaalde lasgewing van die plaaslike gemeente.

Dordt se kerkorde soos geformuleer in 1618-1619, word ten spyte van die patronaatsreg in Nederlandse Hervormde kringe positief waardeer en deur Haitjema bestempel as 'Nedrl. Geref. Kerkrecht [...] geconsolideerd in het presbyteriaalsynodale stelsel van kerkregering met een onmiskenbaar accent van afweer van het independentisme' (Haitjema 1951:27-30).

In vergelyking met hedendaagse kerklike ordes sou die kerkorde van Dordt 1618-1619 eintlik as 'n beperkende kerkorde beskou kon word aangesien kerkordes deesdae aan veel meer aangeleenthede aandag skenk as wat in 1619 nodig geag is. Andersins was die besondere invloed van die owerheid in kerklike aangeleenthede wat ook in die kerkorde van Dordt neerslag gevind het, wesenlik onaanvaarbaar en sou ook in hedendaagse kerke onaanvaarbaar wees. In dié verband kan ook daarop gewys word dat die buitelandse afgevaardigdes wat die vergadering bygewoon het nie deur buitelandse kerke gestuur is nie, maar deur hulle onderskeie landsowerhede, wat aanduiding was van die vanselfsprekendheid dat die owerheid in kerklike sake betrokke was (Pont 1981:187). Die besondere invloed van die owerheid in kerklike sake lei daartoe dat na Dordt nie weer nasionale sinodes plaasgevind het nie totdat die owerheid weereens dit goed gedink het om vir die kerk 'n kerkorde te formuleer bekend as die Algemeen Reglement van 1816. Die inhoud van die Algemeen Reglement verswaar die betekenis van Dordt en verklaar in groot mate waarom Dordt so prominent geag is. 
Daarom dat die kerklike spanning wat sy oorsprong vind in die proponentsformule na 1816 (Haitjema 1964:104-112), ook kerkordelik 'n beroep op Dordt word as verweer teen die Algemeen Reglement (Haitjema 1951:24). Die situasie kan ook as ' $n$ spanning tussen Gereformeerd en Hervormd tipeer word wat in Suid-Afrika redelik skerp lyne getrek het. Dit veral in die lig van hoe die woord gereformeerd in Nederland gebruik word, in vergelyking met gereformeerd en hervormd in Suid-Afrika.

Die kerkorde van Dordt 1618-1619 vind in die Gereformeerde Kerke in Suid-Afrika die getrouste navolging, ten spyte van aanpassing by eie omstandighede (Spoelstra 1989:22) na die aanvanklike aanvaarding tydens die Sinode van Reddersburg van 1862 (vgl. Du Plooy 2015:6). In resente navorsing word Dordt steeds besonder hoog waardeer wanneer die kerkorde van Dordt geag word 'to be an almost unalterable monument' (Van Harten-Tip 2018:248).

\section{Die Algemeen Reglement van 1816}

Ter aanvang kan die bewering gemaak word dat die Algemeen Reglement nie in die kerkregtelike debat positief waardeer word nie en nie as 'n besondere en bruikbare toevoeging beskou word in die Reformatoriese Kerkreg nie, veral gesien teen die omstandighede waarin die Reglement aan die Kerk opgedwing is, asook inhoudelik. Daarom die mening dat die invloed van die Algemeen Reglement ook nie so besonders is as wat beweer word nie.

Wanneer die Dordtse Sinode op 29 Mei 1619 uiteengaan, nadat ook die kerkorde opnuut vasgestel is, ongeag hoe eenstemmig die kerkorde van Dordt daarna deur die verskillende provinsies aanvaar is, is die Algemeen Reglement van 1816 wat op 07 Januarie 1816 van krag geword het, die eerste vasgestelde 'kerkorde' sedert die kerkorde van Dordt - 197 jaar later. Een van die ietwat siniese opmerkings van Noordmans (1984) oor die Algemeen Reglement is van toepassing:

Een der meest kenmerkende eigenaardigheden van de organisatie van 1816 is haar vermogen om te duren. Bij de pogingen om haar te breken zijn geslachten versleten, zonder dat er merkbare ruimte tussen haar voegen kwam. (p. 209; vgl. Bartels 1946)

Dit is feitlik onmoontlik om die Algemeen Reglement positief te waardeer (Pont 1991:106), soos Van Loon (1942:222; vgl. Fiolet 1953:11-30) dit stel:

Het Algemeen Reglement was het resultaat van de miskenning van het eigenaardig recht der kerk, dat door de machtsoverschrijding van de overheid werd gekrenkt, waarbij de kerkorde van de belijdenis geïsoleerd en het ambt gedegradeert werd. (p. 222)

Van Loon beklemtoon dat die oorsprong van die Algemeen Reglement nie in die kerk gevind word nie, maar in die owerheid (vgl. Balke \& Oostenbrink-Evers 1993:XVII) met sy invloed wat in dié tyd veel sterker was as tydens die Sinode van Dordt 1619. Die handhawing van die leer van die kerk was onder druk en die regering van die kerk in kerkregtelike sin het in die hande van 'n klein sinodale kommissie van 'n eweneens klein sinode beland wat ter aanvang in elk geval deur die koning benoem is. Die sinode was saamgestel uit elf predikante, een ouderling en drie teologiese professore (Pont 1991:91; Van den Heuvel 1991:32). Van Loon (1942:187) som die Algemeen Reglement so op: 'saeculariseering, oligarchie, hierarchie, staatsusurpatie en richtingsstrijd.'

Uit die Grondwet van 1814 dui artikel 133 aan dat die 'christelijke Hervormde Godsdienst is die van den souvereinen Vorst' waarin aan die Souvereinen Vorst in artikel 139 die bevoegdheid verleen word 'om zoodanig toezicht over alle de godsdienstige gezindheden uit te oefenen, als voor de belangen van den Staat dienstig zal bevonden worden, [...]' (Haitjema 1951:42; vgl. Hooijer 1848:16). Afgesien van enige godsdienstige of Skriftuurlike relevansie wat in die Reglement gevind word is dit duidelik dat die oorsprong van die Reglement in die owerheid setel en daarom word na die kerk as 'n genootskap verwys, 'n vrywillige vereniging in 'n demokratiese bestel (art. 1). Lidmate bly deel van die genootskap 'zoo lang zij niet vrijwillig en duidelik verklaard hebben, zich daarvan af te scheiden of om wettige redenen daarvan afgescheiden zijn' (art. 2). Klijn (1888:193-195) wys daarop dat die neiging om na die kerk as 'n genootskap te verwys, spruit uit owerheidswetgewing sedert 1797 en 1798 waardeur die kerk as geheel met al sy gemeentes as 'n genootskap gesien is.

Die invoering van die Algemeen Reglement en die onwelkome invloed van die owerheid het verwoestende gevolge vir die kerk gehad wat uiteindelik twee kerklike afskeidings teweeg gebring het. Koning Willem I stel 'n afsonderlike departement in vir Hervormde en ander eredienste waardeur die Algemeen Reglement tot stand kom. Wat die struktuur van die Reglement betref was die opstelling duidelik hiërargies-bestuurlik van aard, wat oorgeneem is uit die denkbeelde van die staat tiperend van die Franse Rewolusie en die Napoleontiese tydvak. Gevolglik was die leer en die handhawing daarvan nie in die sentrum van belangstelling nie, maar veel eerder om die kerk te bestuur (Balke \& Oostenbrink-Evers 1993:XVII-XVIII).

Die verloop, veral vanaf 1852, verskuif weg van die Reglement self na pogings om die kerk te bevry. Van Loon (1942:201) haal Kuyper aan wat die gevolge van die invoering van die Reglement as 'n driedubbele misstand beskou, naamlik: die vryheid van die kerk word deur staatsmag gebind; die selfstandigheid van die kerk word deur 'n kunsmatige meganisme van 'n genootskap opgehef; en die geestelike band word vervang deur 'n niegeestelike reglementêre band.

Van Loon (1942:222) bestempel die Algemeen Reglement as 'n kerk- en staatsregtelike knoop, 'n bitter vrug van die rewolusionêre beginsel waarteen slegs in gehoorsaamheid aan Christus weerstand gebied kan word, 'den eenigen Souverein, uit wien de goede vrucht gevonden moge worden.' 
Soos reeds gestel, word die Algemeen Reglement nie verdedig nie, ten minste nie in kerklike kringe daarna nie en ook nie tot op hede nie. Geen kerk sal genoeë neem met die manier waarop die owerheid die kerk as ' $t$ ware betree het en sodoende die kerklike reg verwring het nie. Daarom is dit sterk te betwyfel of kerkordes van meer resente tye wat kerkordes van reformatoriese kerke in Suid-Afrika insluit, enigsins onder invloed van die Algemeen Reglement van 1816 funksioneer.

\section{Die Kerkorde van die Nederlandse Hervormde Kerk van 01 Mei 1951}

Wanneer die 1951-kerkorde van die Nederlandse Hervormde Kerk (NHK) naas die Algemeen Reglement van 1816 geplaas word, is dit duidelik dat die Algemeen Reglement geen navolging in die nuwe kerkorde van 1951 gevind het nie. Die kerkorde bestaan uit die eerste gedeelte wat as die wesenlike van die orde tipeer kan word, gevolg deur'n reeks ordinansies wat as toepassing op die eerste gedeelte funksioneer. Die Commissie voor de Kerkorde (1945-1950) bestaande uit proff. P. Scholten, S.F.H.J. Berkelbach van der Sprenkel, H. De Vos, T.L. Haitjema, A.A. van Ruler, J. Severijn, drs. H.M.J. Wagenaar, E. Emmen, K.H.E. Gravemeyer, O. Noordmans, di. J. Boonstra, H.J.F. Wesseldijk, W.A. Zeydner en mr. G. Vixseboxse het doelbewus gekies om nie die Dordtse kerkorde sonder meer te handhaaf soos wat in Gereformeerde kringe gebeur het nie, omdat omstandighede drasties verander het en Dordt interne kerklike sake gereël het en te weinig aandag aan die diens van die kerk in en aan die wêreld gegee het. Dordt se hoofmomente was geleë in stryd met die owerheid as gevolg van die invloed van die owerheid in die kerk, asook in stryd met die remonstrante oor die leer van die kerk (Balke \& Oostenbrink-Evers 1993:XXVI-XXXIX; vgl. red. Selderhuis 2006:436). Die keuse om 'n nuwe kerkorde te formuleer was dus nie ' $n$ keuse in navolging van die Algemeen Reglement van 1816 nie. Tog stel die Commissie dat alhoewel Dordt nie nagevolg is nie (Balke \& Oostenbrink-Evers 1993):

[z]al men toch kunnen constateren dat er in het project naar het wezen der dingen een zeer nauwe verwantschap ligt met deze en de haar voorafgegane kerkorden, zoals ook vanzelfsprekend is voor deze majestueuze geestelijke bouwwerken der reformatie. (pp. XXXIX)

Terselfdertyd is sterk standpunt ingeneem teen die Algemeen Reglement van 1816:

De kerkorde van 1816 is tezeer een mislukking en een belemmering voor de kerk geweest, dan het zijn zou hebben haar nieuw leven in te blazen. Haar kenmerken: ongeestelijkheid, ziekelijke casuïstiek, en weinig elegante bouw maken haar bovendien onbruikbaar als startbaan voor een nieuwe kerkorde. Zij heeft zichzelf overleefd en weinig zullen haar verscheiden betreuren. (p.XL)

Dié mening spreek tog vanself en sou dus beteken dat die Algemeen Reglement van 1816 nie verdere navolging gevind het nie en kom daarop neer dat indien Dordt nie formeel, uiterlik en klakkeloos nagevolg is nie, dit nie as navolging van 1816 tipeer kan word nie. Van den Heuvel bevestig dat die Commissie voor de Kerkorde aansluiting gesoek het by Wezel, Emden en Dordrecht waaruit ook blyk dat die kerkinrigting presbiteriaal is en as wesenlike inhoud het dat die kerk sal leef onder heerskappy van Christus en daarom word nadruk geplaas op die funksionering van die drie ampte in die kerk van Christus. Die bedreiginge van die kerk is nie meer net Roomse dwalinge en owerheidsinmenging nie, maar ontkerstening en nihilisme. Daarom moes die apostolies-missionêre taak van die kerk veel sterker beklemtoon word. 'n Christus-belydende kerk hoef nie na menslike insigte te vra nie, maar soek slegs die waarheid van God op grond van sy Woord (Van den Heuvel 1991:34).

Die kerkorde het begin deur te verklaar dat die Nederlandse Hervormde Kerk ooreenkomstig sy belydenis openbaring is van die een heilige Katolieke of algemene Christelike Kerk, wat uit al die Hervormde gemeentes bestaan (NHK 1969:11, art. I). Kragtens die genadeverbond behoort diegene tot die kerk wat rondom Woord en sakrament vergader (NHK 1969:11, art. II). Eie aan ordes uit die reformatoriese kring is die anti-hiërargiese beginsel in artikel V opgeneem. Wat veral aandag trek is die apostolaat van die Kerk soos verwoord in artikel VIII, gevolg deur die belydenis van die Kerk soos geformuleer in artikel X. Hierin is dit duidelik dat die NHK Jesus Christus as Hoof van die Kerk en Heer van die wêreld bely (NHK 1969:13, 16, 17). In die artikel oor apostolaat bely die Kerk as 'n Christus-belydende geloofsgemeenskap (art. VIII) wat deelneem aan die ekumeniese arbeid in Nederland en in die wêreld (NHK 1969:21, art. XXV.1,). In dié verband het die NHK gekies om 'n belydende Kerk te wees wat in alle opsigte en as geheel Jesus Christus as Heer wil bely (vgl. Rasker 1981:317). Van Ruler (1948b) het gesê dit is:

$[D]$ e gehele kerk, welke als belijdende kerk uitkomt. Het is niet een individuele gelovige of een individuele ambtsdrager, welke als subject van het belijden gezien wordt. [...]. De gehele kerk is derhalve primair subject van het belijden. [...]. In de uitdrukking 'de gehele kerk' zijn alle gestalten der kerk - van den enkelen gelovige af tot en met die generale synode-complexief gegrepen. (pp. 18, 19)

Die kerk is nie met verskillende aktiwiteite besig terwyl belydenis van geloof 'n bykomende taak daarnaas plaasvind nie. Die kerk is in alle kerklike geledinge belydend met die evangelie op pad na die wêreld en daarom die sterk klem op die apostolaat, kenmerkend van die 1951 kerkorde wat as sy en keersy, hol en bol, pool en teenpool, van die konfessionele na die apostoliese en omgekeerd, kerk in die wêreld is (Van Ruler 1948a:11).

Klem op die belydende karakter van die kerk asook die apostolêre gerigtheid verwoord die eieaardigheid van die 1951-kerkorde van die NHK en verklaar waarom die kerkorde van Dordt van 1618-1619 nie sonder meer gehandhaaf is nie.

Die kerkorde van die Protestantse Kerk Nederland (PKN) is die kerkorde wat die resultaat is van die herenigde 
voortsetting van die Nederlandse Hervormde Kerk, die Gereformeerde Kerken in Nederland en die EvangelischLutherse kerke wat saamgesmelt het sodat die PKN bestaan uit al die gemeentes van die genoemde kerke (PKN 2004:10). Die kerkorde is die resultaat van die besluit op 14 Maart 1986 van die sinodes van die Nederlandse Hervormde Kerk en die Gereformeerde Kerken in Nederland (GKN) om 'n staat van hereniging te verklaar. Daar is ook ' $\mathrm{n}$ 'Verklaring van Overeenstemming ten aanzien van het samen kerk-zijn' waarin vier kernpunte van belydenis geformuleer is: die regverdiging van die sondaar; die kerk is die liggaam van Christus; die waarheid is ondeelbaar; en die gemeente word geroep om gestuur te word (Van den Heuvel 2004:15). Dit is opvallend dat in die kerkorde van die PKN 'n ooreenkoms met die kerkorde van die NHK gevind word wat ook nie sonder meer tot die kerkorde van Dordt 1618-1619 terugkeer nie, maar wesenlike uitgangspunte bevat wat in 'n kerkorde van reformatoriese statuur verwag word soos: die belydenis van die Kerk (art. 1); Jesus Christus as Heer en Verlosser van die wêreld (art. 1.6); dat gemeentes rondom Woord en sakrament vanweë God se genade en kragtens sy verbond vergader word (art. III.1); so ook die anti-hiërargiese beginsel (art. VI) (PKN 2004:9-13) wat sedert die Sinode van Emden (Kersten 1980:42, art. 1), deel uitmaak van reformatoriese kerkreg.

Dit is opvallend en van kerkregtelike betekenis dat selfs in Nederland uit die geledere van die Gereformeerde Kerken Nederland, Dordt nie strak nagevolg is nie maar 'n kerkorde aanvaar is wat nader aan die kerkorde van die NHK gevind word wat uiterlike vorm en opstelling betref. Die situasie in Suid-Afrika is dat die Gereformeerde Kerke in Suid-Afrika (GKSA) Dordt navolg na bepaalde wysigings (GKSA 2015; Spoelstra 1989:22), terwyl die Nederduitse Gereformeerde Kerk (NGK) en die Nederduitsch Hervormde Kerk van Afrika (NHKA) Dordt nie strak nagevolg het nie.

\section{Kerkorde van die Nederduitsch Hervormde Kerk van Afrika 2016}

Die historiese aanloop van die kerkregtelike debat in die NHKA kan ver teruggevoer word tot die vroeë kerkregtelike reëlings wat sedert en na die koms van Van Riebeeck sedert 06 April 1652 die lig gesien het.

Hierdie artikel is nie ' $n$ poging om die onverkwiklike debat uit die verlede oor die oudste kerk of kerk met die suiwerste leer te laat herleef nie, inteendeel. Die kerkordelike reëlings in die vroeë tyd aan die Kaap sedert die volksplanting was ook nie op die presiese lyne van Dordt geskoei nie waarskynlik omdat Dordt nie algemene aanvaarding geniet het nie, veral in die provinsie Holland waaronder die klassis Amsterdam ingesluit was wat sedert 1652 tot 1814 verantwoordelikheid vir die Kaap aanvaar het, soos reeds aangedui is. Daarom is dit verstaanbaar dat die eerste formele kerkordelike maatreëls, of poging daartoe, De Mist se Provisioneele Kerken-Ordre was wat op 21 Augustus 1804 gepubliseer is (Pont 1991:177; vgl. Brown 1992:692).
Onderlinge kerklike spanning wat dikwels tot uiting gekom het in die historiese verloop en verskil van mening soos tydens die Doleansie, maar ook in die beoordeling van die kerklike situasie aan die Kaap, was die rede vir en aanloop tot kerklike spanning wat later gevolg het (Brown 1992:693, 708-709). Daarbenewens het die politieke gebeure waarbinne die kerk geleef het ook 'n bydraende rol gespeel soos wat in die Kaap gebeur het tydens die anneksasie van die Kaapkolonie en die gevolglike Groot Trek sedert 1834. Daarby kan ook die bydrae van die twee vryheidsoorloë van 1881 en 1899-1902 gevoeg word wat die kerklike lewe onder druk geplaas het en selfs 'n mislukte kerkvereniging in 1885 ingesluit het. In dié verband het die datum vir die ontstaan van die NHKA onder die spervuur gekom en die vraag laat ontstaan of dit in die verloop van die volksplanting gebeur het of dalk eers toe die eerste predikant van dié kerk, ds. Dirk van der Hoff op 27 Mei 1853 in Potchefstroom aangekom het (Engelbrecht 1936:79).

Kerkordelik gesproke het die vorm en inhoud van die kerkregtelike debat in die NHKA sy loop geneem maar bereik ' $n$ besondere mylpaal toe die Kerk in sy Algemene Kerkvergadering (soos die sinodale vergadering van die NHKA bekend staan) van 11 Mei 1948 en die daaropvolgende dae besluit het om die kerkorde te hersien en die taak aan die regskommissie op te dra wat in hulle vergadering van 01 Junie 1948 besluit het om eksemplare van die kerkorde in ontwerp van die Nederlandse Hervormde Kerk te bekom (Van Wyk 1991:171).

In die verslag van die regskommissie wat by voltooiing van die nuwe kerkorde (kerkwet) voorgelê is aan die Algemene Kerkvergadering van 08 Maart 1951, word daarop gewys dat die belydenis en die apostoliese karakter van die Kerk prominent aandag gekry het aangesien die Kerk toenemend standpunt moet inneem teen ontkerstening en verwildering. Die Kerk mag nie in sigself gekeer wees nie, maar moet met die evangelie van die koninkryk van God bewustelik en doelgerig Kerk wees. Die nuwe kerkordelike maatreëls, wat merkwaardig genoeg (ongelukkig) as 'n kerkwet tipeer is, het in 1951 tot stand gekom wat anders daar uitsien as die kerkregtelike ontwikkeling sedert 1824 met 'n kerkorde wat veel sterker uit die Hervormde Kerk self tot stand gekom het (vgl. Van Wyk 1991:173-174).

Die 1951-kerkwet van die NHKA het bly voortbestaan totdat 'n nuwe kerkorde in 1997 aanvaar is wat ook sedertdien as kerkorde bekend staan. In die verlenging van die 1997-kerkorde is die kerkorde van die NHKA wat tydens die 71ste Algemene Kerkvergadering in 2016 na bepaalde wysigings, opnuut vasgestel is.

Omgang met die 2016-kerkorde van die NHKA sal met die eerste oogopslag uitwys dat die opstelling van die 1951-kerkorde van die NHK behou is met betrekking tot die kerkorde wat geformuleer is in tien hoofstukke, bestaande uit Ordereëls, telkens gevolg met ordinansies wat as die verdere uitleg van die kerkorde gesien kan word. 
Daarnaas sou ook die gewone besluite wat tydens 'n Algemene Kerkvergadering geneem word as verdere uitleg van die kerkorde beskou kon word. Nader besien is die gedeeltes in vetdruk aan die begin van elke Ordereël die wesenlike van die kerkorde, gevolg deur die nadere verklaring wat in die res van die Ordereël bygevoeg word. Dat die Ordereëls belangriker geag word as die Ordinansies word duidelik as in ag geneem word hoe Ordereëls en Ordinansies tot stand kom en gewysig word (vgl. NHKA 2016:98).

Met die diskussie van die eie kerk en sy kerkorde moet daarop gewys word dat daar in die kerkregtelike debat tydens die hersienings wat tot die kerkorde van 1997 gelei het, asook die hersiene kerkorde van 2016 geen enkele verwysing of inagneming van die Algemeen Reglement van 1816, ter sprake gekom het nie. Die feit is gemaklik verklaarbaar in die sin dat die Algemeen Reglement van 1816 géén rol speel in die kerkregtelike denke van die NHKA nie. Die invloed en die rol van die owerheid soos verwoord deur die Algemeen Reglement van 1816 is onaanvaarbaar en boonop ook nie die intensie van die owerheid in die huidige Suid-Afrikaanse regstaat nie. Hoe onwelkom dit kan wees is duidelik wanneer die patronaatsreg in die Dordtse kerkorde van 1618-1619 in ag geneem word.

In die kerkorde van die NHKA word pertinent gestel dat 'Jesus Christus die enigste Hoof van die kerk' is (NHKA 2016:42, Ordereël 4), wat beteken dat ampsdraers niks anders is as dienaars van Jesus Christus nie en gevolglik heers die een vergadering nie oor die ander vergadering nie en die een amp nie oor die ander nie.

Dit is die bekende anti-hiërargiese beginsel wat reeds by Emden in artikel 1 gevind word (Kersten 1980:41).

Die uitgangspunt dat Jesus die enigste hoof van die Kerk is, word in Ordereël 8 herhaal (NHKA 2016:82).

Die hoofskap van Christus word dus ter aanvang bevestig wanneer die kerkorde in Ordereël 1 (NHKA 2016:1) bevestig dat die NHKA in gemeenskap met die Kerk van alle eeue sy geloof bely in die Drie-enige God, Vader, Seun en Heilige Gees. Onmiddellik in dieselfde Ordereël word verwys na die drie ekumeniese belydenisskrifte, asook na die drie formuliere van eenheid. Die bewering dat Ordereël 1 wat oor die belydenis van die Kerk handel, dui op ' $n$ voortsetting van die Algemeen Reglement van 1816, omdat die belydenis van lidmate die basis van hulle verbintenis met die Kerk sou vorm, is nie korrek nie. Nel (2019) vervolg met die volgende mening:

The departure point is the faith of its members. It constitutes the church (singular) around the faith (confession) of its members as a voluntary society. Local churches are not primarily bound together by Christ, but by the individual free will of its members. (p. 166)

Lidmaatskap van die NHKA is nie op vrywillige toetrede gebaseer nie, maar geskied op die uitverkiesing van God deur genade wat deur die Heilige Gees in Jesus Christus tot geloof kom en deel van die volk van God vorm (NHKA
2016:5, Ordereël 2), soos ook aangedui word deur die Heidelbergse Kategismus, vraag en antwoord 54 (NHKA 2012:21). Lidmaatskap van die kerk is nie soos lidmaatskap van 'n sosiale vereniging wat gebeur op grond van 'n vrywillige keuse deur 'n bepaalde individu nie. Die feit word herhaal in Ordereël 2.1, naamlik dat die Kerk 'n gemeenskap van gelowiges is wat deur God se versoening in Christus tot stand gebring is (NHKA 2016:5). Wanneer direk in Ordereël 2.2 met betrekking tot lidmaatskap gestel word dat lidmate van die Kerk diegene is wat kinders van lidmate van die gemeente is, wat deur die doop en belydenis van geloof dooplidmate en belydende lidmate van die Kerk geword het, moet dit saam gelees word met die voorafgaande wat erns maak met die feit dat die Kerk nie setel in die vrywillige samekoms van lidmate nie.

In die kerkorde van die NHKA word inderdaad na die NHKA in die enkelvoud verwys aangesien daar net een Hervormde Kerk is wat uit al sy gemeentes bestaan en as ecclesia completa funksioneer en nie deur 'n kerkverband saamgesnoer word op 'n konfederatiewe basis nie. Dit dui op 'n growwe mistasting om op grond van Ordereël 7 waar gestel word dat die Kerk 'n verskyningsvorm is van die een, heilige, algemene, apostoliese kerk en geroepe is om eenheid en gemeenskap met ander kerke na te streef en samewerking te bevorder, te beweer dat die sigbare en onsigbare kerk 'does not intersect, but is seperated', met die slotsom dat die NHKA daarmee voortsetting met die Algemeen Reglement van 1816 verwoord (vgl. Nel 2019:167).

Wanneer Ordereël 4 die hoofskap van Christus beklemtoon word ampsdraers daarmee sonder meer tot dienaars gereken wat in die vergaderings van die ampte byeenkom om hulle opdrag uit te voer wat bestaan in verkondiging, toerusting, opbouing, versorging, beskerming, regering en leiding van die Kerk. Die vergaderings van die ampte, die kerkraad, ringsvergadering en Algemene Kerkvergadering, neem besluite op grond van die Bybel, in ooreenstemming met die belydenis van die kerkorde, met inagneming van die gebruike van die Kerk, nie om die Kerk te bestuur nie, maar te regeer, wat in kerkregtelike sin totaal anders is as wat demokraties beleef word.

Die vergaderings van die ampte is ook nie hiërargies opgestel nie, maar behandel die sake wat deur die kerkorde aan die vergadering opgedra is (NHKA 2016:42, Ordereël 4.2). Orde in die Kerk is dus nie juridies van aard nie en die kerkorde is ook nie 'n juridiese dokument wat net deur regsgeleerdes verstaan en uitgelê word nie, want die agtergrond waarteen die kerkorde van die NHKA funksioneer is 'n Skriftuurlike agtergrond, en derhalwe 'n poging om in die Kerk aan die hand van die Woord, om Christus wil te leef (vgl. Nel 2019:167).

Sinodale, meerdere- of bykomende vergaderings neem, met betrekking tot die opdrag wat hulle geniet volgens kerkorde, bindende besluite. Dit beteken nie dat die besluit van 'n sinodale vergadering bindend is net omdat daar meer afgevaardigdes byeen is as by die plaaslike kerkraad nie, want die Kerk is nie 'n parlementêre demokrasie nie, maar 'n 
pneumatiese Christokrasie (vgl. Pont 1982:121), wat daarop neerkom dat die Woord van God, in alle vergaderings ewe sterk funksioneer en besluite dus nooit bindend en rigied vir tyd en ewigheid geneem is nie. Dit is dus nie korrek om die moontlikheid van veral ' $n$ sinodale vergadering wat bindende besluite kan neem, te interpreteer asof die Woord nie gesag het nie, behalwe die meerderheid van die vergadering nie (vgl. Nel 2019:168). Die kerkorde is duidelik dat vergaderings besluite neem op grond van die Woord van God (vgl. NHKA 2016:42, Ordereël 4.1).

In die kerkorde van Dordt word in artikel LXXXVI gestel dat besluite 'met gemeen akkoord' geneem is en nie na goeddunke verander kan word nie (Kersten 1980:194). In die kerkregtelike debat het die uitgangspunt bekend geraak as die antiindependentistiese beginsel wat ook in die kerkorde van die NHKA opgeneem is (NHKA 2016:56, Ordereël 4.4).

Binding aan kerklike besluite is nie' $n$ juridiese aangeleentheid soos wanneer 'n hof op grond van burgerlike wetgewing 'n uitspraak maak in 'n saak nie, maar ter wille van die goeie orde. Dit kan inderdaad verskil van mening tot gevolg hê, maar kan nie deur eiesinnige optrede soos deur staking in die kring van arbeidsonrus weerlê word nie, maar moet op kerklike wyse hanteer word. Daarom bestaan die moontlikheid van appèl (NHKA 2016:85, 90, Ordinansies 8.1 .3 ; 8.9) wanneer verskil van mening oor besluite ontstaan, want die vraag is nie of die meerderheid, die groot sinodale vergadering so besluit het nie, maar of die besluit Skriftuurlik houdbaar is al dan nie. Dit was al in die kerkorde van Dordt 1618-1619 ingeskryf (Kersten 1980:183, art. XXXI).

Die sinodale vergadering is dus nie die hoogste gesag in die Kerk nie, trouens daar is slegs sprake van Woordgesag wat nie kerklik-demokraties bepaal word nie. Die inslag van die kerkorde van die NHKA het nie 'n hiërargiese opstelling nie, want elke vergadering handel ooreenkomstig die bevoegdheid wat aan hom verleen is en staan nie in hiërargiese verhouding tot mekaar nie.

Ordereël 10.5, waar die reg van usansie ter sprake kom, kan nie geïnterpreteer word as bevestiging van die feit dat die enigste terreine waar die gemeentes vryheid gegun word om in die lig van die Woord te handel, daardie situasies is wat nie eksplisiet in die kerkorde omskryf is nie (vgl. Nel 2019:168). Die opstelling van die kerkorde is 'n maksimum-minimum uitgangspunt en derhalwe is die kerkorde nie 'n notule van kerklike gebeure nie en word daar nie voorsiening gemaak vir die besondere omstandighede van elke gemeente nie.

Ordereël 10.5 kom daarop neer dat daar te alle tye aan die hand van die Woord gehandel moet word, ongeag of die situasie in die kerkorde omskryf is al dan nie.

\section{Die bewering volgens Nel (2019) dat:}

[The] mere structure of the Church Order of the NHKA suggests a formal relation with the General Regulation as it begins (just after the judicial binding of the confessions) with membership. (p.170) is nie korrek nie aangesien die kerkbegrip in Ordereël 2 ter sprake kom, synde 'n Kerk wat sy oorsprong in Christus beleef wat onder leiding van die Heilige Gees kerk van Christus is. Dit lê redelik duskant lidmaatskap wat bestaan uit vrywillige toetrede om weer eweneens vrywillig die kerklike gemeenskap te verlaat, om sodoende die kerk te vervlak tot maar net nog 'n sosiale vereniging van mense.

Verder word daarop gewys dat van voornemende bedienaars van die Woord verwag word om by toelating die proponentsformule (NHKA 2016:20, Ordinansie 3.1) te onderteken wat duidelik op die quia standpunt funksioneer as van diesulkes verwag word om die leer wat in die formuliere van eenheid ter sprake kom te aanvaar omdat dit in ooreenstemming is met die Woord van God. Daarnaas word ook aanvaar dat aan die kerkorde gehou sal word, nie omdat die kerkorde 'n juridiese dokument is nie, maar eerder ekklesiologie is wat in die verlenging van die Skrif funksioneer.

\section{Slotopmerkings}

Die proponentsformule en die quia en quatenus debat was die middelpunt van die forse kritiek wat teen die Algemeen Reglement van 1816 gevoer is wat uiteindelik tot kerklike afskeidings gelei het (vgl. Rasker 1981:41-42). Die sterk weerstand teen die Reglement wat uit die geledere van die Nederlandse Hervormde Kerk gevoer is sodat eers op 01 Mei 1951 daarin geslag is om die kwalike Algemeen Reglement te vervang, dui daarop. In dié verband kan maar die moeite gedoen word om Noordmans (1984) se werk te lees wat 'n goeie beeld is van die felheid van die stryd. Die kerk is in 1816 sterk aan bande gelê deur Koning Willem 1 wat (vgl. Rasker 1981:22,36) deur die kerk te wou bestuur en die verwarrende kerklike toestande na die Napoleontiese oorloë, weer finansieel en andersins te orden onder die indruk dat dit vir die kerk ten goede was. In dié verband het woordvoerders soos Kuyper en Hoedemaker teenoor mekaar te staan gekom.

Kuyper had meer de vrije kerkvorm in Engeland en Amerika tot voorbeeld genomen, [...]. Hoedemaker sloot zich dichter aan bij de Nederlandse tradities. Zijn bedoeling was om met: heel de kerk en heel het volk te rekenen. Hij vergeleek de kerk met een man die onder een balk vandaan gehaald moes worden. Die balk was die organisatie van 1816. Maar men mocht daarbij, wilde men zijn leven ontzien, niet gaan amputeren. (Noordmans 1984:125-127)

Dit is nie genoeg om met Rooijaards te volstaan in sy indruk dat die Algemeen Reglement 'n positiewe ontvangs geniet het nie as 'a welcome solution and an end to the consequences of total seperation of state and church at the time' ( $\mathrm{Nel} 2019: 106-107)$. Met die nagaan van Rooijaards (1834:17-18) word nie die indruk gekry van sy ongekwalifiseerde waardering vir die 1816 Reglement nie. Met verwysing na die bronne van die Nederlandse Hervormde Kerk dui hy aan dat elke regsbepaling op die Skrif berus, op die leer gegrond op Christus en die apostoliese uitsprake. Dit dui nie op blindelingse goedkeuring van die Algemeen Reglement nie en staan wesenlik in kontras met die Algemeen Reglement wat uit die staanspoor vanuit die Classis Amsterdam krities 
bejeën is (Rooijaards 1834:61). Dit ten spyte van die aanname dat in die periode 1843-1859, 38 studente van Suid-Afrika in Utrecht studeer het waar Rooijaards verbonde was en hy sodoende invloed op die Suid-Afrikaanse kerklike situasie uitgeoefen het (Nel 2019:31).

Weerstand teen die Algemeen Reglement het spoedig gevolg, nie net uit die kringe van die Doleansie nie, maar ook uit kerklike geledere soos verwoord deur Hoedemaker, asook uit etiese en vrysinnige kringe (Noordmans 1984:126-129). Chantepie de la Saussaye het hom oor die organisasie van 1816 sterk uitgespreek as 'een Nederlandse uitvinding van de negentiende eeuw' en 'de ongerijmdheid zelve zonder weerga in de geschiedenis' (aangehaal deur Noordmans 1984:129).

Verder is dit ' $\mathrm{n}$ redelik reglynige aanname dat indien gebruik gemaak is van die 1951-kerkorde van die NHK, dit sonder meer daarop dui dat die gevolg funksioneer onder invloed van die Algemeen Reglement van 1816 (Nel 2019:164, 185). Miskien kom dit neer op'n ietwat reglynige aanname dat alle afwykings van Dordt sonder meer óf kollegialisties óf ten minste onder invloed van die Algemeen Reglement die lig gesien het.

\section{Erkenning \\ Mededingende belange}

Die outeur verklaar dat hy geen finansiële of persoonlike verbintenis het met enige party wat hom nadelig kon beïnvloed in die skryf van hierdie artikel nie.

\section{Outeursbydrae}

B.J.v.W. was die enigste outeur betrokke by die skryf van die artikel.

\section{Etiese oorwegings}

Hierdie artikel volg alle etiese standaarde vir navorsing.

\section{Befondsing}

Hierdie navorsing het geen spesifieke toekenning ontvang van enige befondsingsagentskap in die openbare, kommersiële of nie-winsgewende sektore.

\section{Data beskikbaarheidsverklaring}

Data-deling is nie van toepassing op hierdie artikel nie, aangesien geen nuwe data in hierdie studie geskep of ontleed is nie.

\section{Vrywaring}

Die sienings en menings wat in hierdie artikel uitgedruk word, is dié van die outeur (s) en weerspieël nie noodwendig die amptelike beleid of posisie van enige geaffilieerde agentskap van die outeurs nie.

\section{Literatuurverwysings}

Balke, W. \& Oostenbrink-Evers, H., 1993, De commissie voor de Kerkorde (1945-1950), Boekencentrum, Zoetermeer.

Bartels, H., 1946, Tien jaren strijd om een belijdende kerk, Van Stockum \& Zoon, Den Haag.

Brown, E., 1992, 'Die hervertolking van die paradigma in verband met die Kollegialisme om die Afrikaanse kerke kerkregtelik te verstaan', HTS Teologiese Studies/Theological Studies 48(3 \& 4), 691-715. https://doi.org/10.4102/hts. $\mathrm{v} 48 \mathrm{i} 3 / 4.2436$

Doornbos, K., 1967, De synode van Dordrecht 1618/19 getoetst aan het recht der kerk, Buijten \& Schipperheijn, Amsterdam.

Du Plooy, A.L.R., 2015, 'Inleiding op die Kerkorde van die Gereformeerde Kerke in Suid-Afrika', in Kerkordeboekie van die Gereformeerde Kerke in Suid-Afrika soos gewysig deur verskillende sinodes, pp. 6-14, CJBF, Potchefstroom.

Engelbrecht, S.P., 1936, Geskiedenis van die Nederduitsch Hervormde Kerk van Afrika, De Bussy, Pretoria.

Fiolet, A., 1953, Een kerk in onrust om haar belijdenis, Callenbach, Nijkerk.

Florijn, H., 1987, 'De afgevaardigden en geciteerden', in W. Van 't Spijker, C.C. De Bruin, H. Florijn, A. Moerkerken \& H. Natzijl (reds.), De Synode van Dordrecht in 1618 en 1619, pp. 57-94, Den Hertog, Houten.

Gereformeerde Kerke in Suid-Afrika (GKSA), 2015, Kerkordeboekie van die Gereformeerde Kerke in Suid-Afrika soos gewysig deur verskillende sinodes, CJBF, Potchefstroom.

Haitjema, T.L., 1951, Nederlands Hervormd kerkrecht, Callenbach, Nijkerk.

Haitjema, T.L., 1964, De nieuwere geschiedenis van Neerlands Kerk der Hervorming, Boekencentrum, 's-Gravenhage.

Hooijer, C., 1848, Alphabetisch register op de wetten en besluiten vervat in de verzameling der Kerkelijke Wetten, Noman en Zoon, Zalt-Bommel.

Kersten, G.H., 1980, Kerkelijk handboekje, de Banier, Utrecht.

Klijn, H.G., 1888, Algemeene kerk en plaatselijke gemeente, Morks, Dordrecht.

Nederduitsch Hervormde Kerk van Afrika (NHKA), 2012, 'So glo ons', Nederduitsch Hervormde Kerk van Afrika, Pretoria.

Nederduitsch Hervormde Kerk van Afrika (NHKA), 2016, Kerkorde van die NHKA, Nederduitsch Hervormde Kerk van Afrika, Pretoria.

Nederlandse Hervormde Kerk (NHK), 1969, Kerkorde der Nederlandse Hervormde Kerk.

Nel, P.J., 2019, 'A theological-historical investigation of the Church Order of Dordt (1619) and the General Regulation (1816) in the church orders of reformed churches in South Africa', M-dissertation, University of the Free State.

Noordmans, O., 1984, Verzamelde werk, deel V, Kok, Kampen.

Pont, A.D., 1981, Die historiese agtergronde van ons kerklike reg, deel 1, HAUM, Pretoria.

Pont, A.D., 1982, 'Die betekenis van die meerdere vergaderinge ten opsigte van hulle gesag, funksie en handelinge in die kerk', HTS Teologiese Studies/Theological Studies 38(2\&3), 104-135. https://doi.org/10.4102/hts.v38i2/3.4263

Pont, A.D., 1991, Die historiese agtergronde van ons kerklike reg, deel 2, Kital, Pretoria.

Protestantse Kerk Nederland (PKN), 2004, Generale Synode van die Protestantse Kerk in Nederland 2003, Kerkorde 2004, Boekencentrum, Zoetermeer.

Rasker, A.J., 1981, De Nederlandse Hervormde Kerk vanaf 1795, Kok, Kampen.

Rooijaards, H.J., 1834, Hedendaagsch Kerkrecht bij de Hervormden in Nederland, Altheer, Utrecht.

Selderhuis, J. (red.), 2006, Handboek Nederlandse Kerkgeschiedenis, Kok, Kampen.

Spoelstra, B., 1989, Gereformeerde kerkreg en kerkregering, V\&R, Pretoria.

Van den Heuvel, P., 1991, De Hervormde Kerkorde, een praktische toelichting, Boekencentrum, Zoetermeer.

Van den Heuvel, P., 2004, De toelichting op de kerkorde van de Protestantse Kerk in Nederland, Boekencentrum, Zoetermeer.

Van Harten-Tip, A., 2018, De Dordtse Kerkorde 1619. Ontwikkeling, Context en Theologie, Theologische Universiteit van de Christelijke Gereformeerde Kerken in Nederland.

Van Loon, J.C.A., 1942, Het Algemeen Reglement van 1816, Akademiese proefskrif, Universiteit van Amsterdam, Zomer \& Keuning's, Wageningen.

Van Ruler, A.A., 1948a, Het apostolaat der kerk en het ontwerp-kerkorde, Callenbach, Nijkerk.

Van Ruler, A.A., 1948b, De belijdende kerk in de nieuwe kerkorde, Callenbach, Nijkerk.

Van Wyk, B.J., 1991, Die presbiteriaal-sinodale kerkbegrip, Kital, Pretoria. 